\title{
Perception Level of the Women about Performance of Self Help Group
}

\author{
B. Nakum Pooja ${ }^{1 *}$, V.J. Savaliya ${ }^{1}$, B.N. Kalsariya ${ }^{2}$ and S.M. Makwana ${ }^{3}$ \\ ${ }^{1}$ Department of Agriculture Extension, ${ }^{3}$ Department of Horticulture, College of Agriculture, \\ JAU, Junagadh, India \\ ${ }^{2}$ Polytechnic College in Agriculture, JAU, Sidsar, Junagadh, India \\ *Corresponding author
}

\section{Keywords}

Self help group,

Socio-

Psychological impact, Perception

Article Info

Accepted:

15 October 2018

Available Online:

10 November 2018

\section{A B S T R A C T}

Perception is an activity through which an individual becomes aware of objects around oneself and of events taking place. The perception of the SHG members regarding the economic, social, psychological and political influence of SHGs' activities had been analyzed with the help of a developed scaling technique. The study was conducted in three talukas of Junagadh district of Saurashtra region on the basis of maximum number of active SHGs in Junagadh district. A multistage purposive and random sampling technique was followed for the study. Ten SHG members from each selected village were selected for the study and thus, total 90 respondents were selected for study. Performance level of SHG was measured against 15 performance indicators. The result of the finding indicated that majority of the members (60.00 per cent) opined that monthly meeting is held in their SHG, while 50 to 75 per cent attendance was maintained by 51.11 per cent of the members, about three fourth of the members ( 74.45 per cent) conducted meeting by $\mathrm{NGO} /$ Mission Mangalam staff. Whereas, more than two third of members (67.78 per cent) contributed the fund as and when possible; and majority of the SHG members (54.45 per cent) were written records by one of the member. Among the all SHG members records were moderately (not so neatly written) maintained ( 48.89 per cent), saving book amount matched with the passbook ( 63.33 per cent), members of their respective group had not transacting with the bank (52.22 per cent), participated in the extension programme conducted inside their village (56.67 per cent), participated in extension programme organized outside the village (53.33 per cent), group had availed revolving fund Rs.25, 000 to Rs. 50,000 (64.45 per cent), regular in repayment of bank loan (56.67 per cent), repayment of internal loan (64.45 per cent), democratic type of decision making patterns (78.89 per cent) and conflicts rarely arise in their group (77.78 per cent).

\section{Introduction}

A Self Help Group is a group of people possessing a common experience, problem and condition or situation who come together to share their experience, knowledge, ideas and to give and receive support from others.
The formation of group starts with periodical saving of small amount of money. Once the group accumulates sufficient amount of money, then it will be encouraged to take up various income generating activities either as a form of a group initiative or as an activity of the individual member. 
Perception is an activity through which an individual becomes aware of objects around oneself and of events taking place (Ray G. L.). The study was conducted on the perception of SHG members about performance of SHG. The perception of the SHG members regarding the economic, social, psychological and political influence of SHGs' activities had been analyzed with the help of a developed scaling technique.

\section{Materials and Methods}

The study was conducted in Junagadh district of Saurashtra region. A multistage purposive and random sampling technique was followed for this study. Out of nine talukas of Junagadh district, three talukas viz., Junagadh, Mangarol and Visavadar were selected on the basis of maximum number of active SHGs in Junagadh district. From each selected taluka, three villages were selected randomly. Thus, total nine villages were selected. Ten SHG members and ten Non SHG members from each selected village were selected for the study and hence 90 SHG members and 90 Non SHG members were selected using random sampling technique. Thus, total 180 respondents were selected for study. The pretesting of the respondents also carried out which was not considered as sample size.

Performance level of SHG was measured against 15 performance indicators; i.e. frequency of meeting, attendance of the members in the meeting, method of conducting meeting, contribution of individual savings, writing of group records, records maintenance, accounts cross-reference, bank transactions, participation in extension programmes inside the village, participation in extension programmes outside the village, matching or revolving fund benefit to the SHG, repayment of loan to bank, recovery of internal loan, decision making pattern and conflicts in the group.
Performance of each indicator was measured on three point rating scores ranging between 2 , 1and 0 according to responses of the respondents sought for each indicator and total score was arrived by summing up the individual scores. The performance of SHG was measured on the basis of the frequency and percentage.

\section{Results and Discussion}

The result of the finding indicated that among all the SHG members, 60.00 per cent members opined that monthly meeting is held in their SHG, followed by 27.78 per cent and 12.22 per cent SHG members opined that meeting is held fortnightly and weekly, respectively. This might be due to it is difficult to maintain frequent contacts with SHG members, to discuss different agenda and to carry out weekly transactions of the group.

Majority of the respondents (51.11 per cent) were maintained attendance i. e. 50 to 75 per cent. While more than one third (37.78 per cent) of the members had attended meetings i.e. more than 75 per cent and only 17.78 per cent of SHG members attended meeting i.e. 25 to 50 per cent which was organized by their respective group. The conducting and attending the meeting is one of the governing norms agreed upon by almost all SHGs because meetings are the work platform for the SHGs where they carry out regular savings, account maintenance, loan disbursement and planning of future activities apart from building the feeling of belongingness.

Nearer to three fourth (74.45 per cent) of the members opined that the meeting was conducted by themselves by choosing president. While 14.44 per cent of the members conducted the meetings without assigning responsibility to anyone in order to ensure the smoothly conducted and organized 
discussions. Only 11.11 per cent of members conducted the meeting by $\mathrm{NGO} /$ Mission Mangalam staff in their SHG. The need to choose the president might not be felt by these groups perhaps due to the groups' cohesiveness or feeling of responsibility by every member of group.

More than two third (67.78 per cent) members contributed the fund as and when possible by them, which might be due to irregular income source and poverty. While in 27.78 per cent SHG, individual savings were contributed on the fixed day, which showed that they follow the norms of the SHGs and maintain punctuality. And only 4.44 per cent members had skipped contribution in common fund/ saving of their SHGs, which might be due to dependency of female on male's income, lack of support of family for contributing in SHG and poverty.

With respect to writing of group records, in 54.45 per cent of SHG, records were written by one of the member, because of availability of well educated person in the group. Whereas 44.44 per cent of members' SHG got the help of NGO/ Mission Mangalam staff members to write their records, which might be because of good rapport of SHG members with $\mathrm{NGO} /$ Mission Mangalam staff members and only 1.11 per cent SHG were hired the person from village for writing the group records. This might be due to non-availability of welleducated person in their SHG.

Among the all SHG members records were moderately (not so neatly written) maintained as per opinion of 48.89 per cent of the respondents. While records were very well maintained as perceived by 41.11 per cent of members which reflects the transparency of the group and only 10.00 per cent opined that SHG had not maintained the records properly which shows the carelessness of the group members.
Near about two third (63.33 per cent) of the respondents perceived that the saving book amount was matched with the passbook. The reason might be good transactions, repayment and neat maintenance of records with bank and also within groups. While 27.78 per cent members opined that group record showed that slight differences were observed between amounts of group savings book and pass book. It might be due to delay in updating the records, but it is important to correct the difference and ensure that records especially of financial matters are maintained meticulously. While only 8.89 members perceived that there was a lot of difference in the records of pass book and account book.

Among the all respondents, 52.22 per cent of SHG members said that only few members of their respective group were not transacting with the bank, probably because of group's decision to extend the responsibility to the few active members. While 28.89 per cent of SHG members had transacted with the bank, but not all the members.

The findings revealed that one or two members in the group were hesitant, even after joining the SHG, to visit the bank. Only 18.89 per cent respondents said that all the members visited and transacted in bank on behalf of SHG which reflected the transparency in group dealings.

The data also showed that 56.67 per cent of the members opined only some of their group members had participated in the extension programme conducted inside their village. While 27.78 per cent respondents said that majority members participated in extension programmes organized inside the village. While only 15.55 per cent members responded that single person had not participated in the extension programme held in their village. This might be due to lack of interest, lack of time and lack of confidence etc. (Table 1). 
Table.1 Perception of members about performance of SHG ( $n=90)$

\begin{tabular}{|c|c|c|c|}
\hline Sr. No. & Particulars & Frequency & Per cent \\
\hline 1. & Frequency of meeting & & \\
\hline (a) & Weekly & 11 & 12.22 \\
\hline (b) & Fortnightly & 25 & 27.78 \\
\hline (c) & Monthly & 54 & 60.00 \\
\hline 2. & Attendance of the members in the meeting & & \\
\hline (a) & More than 75 per cent & 34 & 37.78 \\
\hline (b) & 50-75 per cent & 46 & 51.11 \\
\hline (c) & $25-50$ per cent & 10 & 11.11 \\
\hline 3. & Method of conducting meeting & & \\
\hline (a) & $\begin{array}{l}\text { Members meet and conducted the meeting by themselves } \\
\text { by choosing president }\end{array}$ & 67 & 74.45 \\
\hline (b) & $\begin{array}{l}\text { Members conducted the meeting without assigning } \\
\text { responsibility to any one }\end{array}$ & 13 & 14.44 \\
\hline (c) & NGO / Mission Mangalam staff facilitates the meeting & 50 & 11.11 \\
\hline 4. & Contribution of individual savings & & \\
\hline (a) & All contribute on the day fixed & 25 & 27.78 \\
\hline (b) & Contributes as and when possible & 61 & 67.78 \\
\hline (c) & Some members would skip contribution & 4 & 4.44 \\
\hline 5. & Writing of group records & & \\
\hline (a) & By one of the members & 49 & 54.45 \\
\hline (b) & By hired person from village & 1 & 1.11 \\
\hline (c) & By NGO/ Mission Mangalam staff & 40 & 44.44 \\
\hline 6. & Records maintenance & & \\
\hline (a) & Very well maintained (up to date neatly written) & 37 & 41.11 \\
\hline (b) & Moderately maintained (not so neatly written) & 44 & 48.89 \\
\hline (c) & Not maintained well (not contain up to date data) & 9 & 10.00 \\
\hline 7. & Accounts cross-reference & & \\
\hline (a) & Balance matches with bank pass book and accounts book & 57 & 63.33 \\
\hline (b) & $\begin{array}{l}\text { Slight difference between group savings book and bank } \\
\text { pass book }\end{array}$ & 25 & 27.78 \\
\hline (c) & Lot of difference & 08 & 8.89 \\
\hline 8. & Bank transactions & & \\
\hline (a) & $\begin{array}{l}\text { All the members visited and transacted in bank on behalf of } \\
\text { SHG }\end{array}$ & 17 & 18.89 \\
\hline (b) & Majority of them transacted & 26 & 28.89 \\
\hline (c) & Only some of them transacted & 47 & 52.22 \\
\hline 9. & Participation in extension programmes inside the village & & \\
\hline (a) & Majority of them participated & 25 & 27.78 \\
\hline (b) & Only few of them have participated & 51 & 56.67 \\
\hline (c) & None has participated & 14 & 15.55 \\
\hline
\end{tabular}




\begin{tabular}{|l|l|l|l|}
\hline 10. & Participation in extension programs outside village & 26 & 28.89 \\
\hline (a) & Majority of them participated & 48 & 53.33 \\
\hline (b) & Only few of them have participated & 16 & 17.78 \\
\hline (c) & None has participated & 22 & 24.44 \\
\hline 11. & Matching or revolving fund benefit to the SHG & 58 & 64.45 \\
\hline (a) & Availed more than ₹ 50,000.00 & 10 & 11.11 \\
\hline (b) & Availed ₹ $25,000.00-₹ 50,000.00$ & & \\
\hline (c) & Less than ₹ 25,000.00 & 51 & 56.67 \\
\hline 12. & Repayment of loan to bank & 39 & 43.33 \\
\hline (a) & Regular & 00 & 00.00 \\
\hline (b) & Irregular & & \\
\hline (c) & Defaulter & 20 & 22.22 \\
\hline 13. & Recovery of internal loan & 58 & 64.45 \\
\hline (a) & Very good & 12 & 13.33 \\
\hline (b) & Good & & \\
\hline (c) & Poor & 71 & 78.89 \\
\hline 14. & Decision making pattern & 10 & 11.11 \\
\hline (a) & All the members are consulted while deciding (democratic) & 09 & 10.00 \\
\hline (b) & Two/ three members decide and others follow & & \\
\hline (c) & Only one member (authoritative) & 7 & 7.78 \\
\hline 15. & Conflicts in the group & 70 & 77.78 \\
\hline (a) & Conflicts arise very frequently & 13 & 14.44 \\
\hline (b) & Rarely occur & & \\
\hline (c) & No conflicts at all & & \\
\hline
\end{tabular}

In case of extension participation, majority of the SHG members (53.33 per cent) said that among the all group members, only few of them had participated in extension programme organized outside the village. While, 28.89 per cent respondents said that majority of the group members had participated in the extension programmes held at outside the village. It should be noted that the extent of extension participation depends upon the number and kind of programmes conducted. The duration and distance of the programmes also influence the level of participation and with this reason 17.78 per cent members opined that nobody participated in the extension programmes which were conducted outside the village. Nearly twothird (64.45 per cent) members of that the group had availed revolving fund $₹ 25,000 /-$ to $₹ 50,000 /-$, while 24.44 per cent members of SHG had availed the revolving fund more than ₹ 50,000/-. Only 11.11 per cent members of SHG had availed the revolving fund benefits less than ₹ 25,000/-. This might be depends on SHG's initiation to contact bank and impress upon effective and credible functioning.

Majority of the respondents (56.67 per cent) said that SHGs were regular in repayment of bank loan. The advantage in SHGs is that of group pressure and the need to maintain trustworthiness with banks to ensure that bank would continue to support and sanction loan in future. While remaining members (43.33 per cent) said that their SHGs were irregular in repayment of loan to bank. This might be that the women were also help to her family like education of her children, to her family members, to buy provisional items etc. 
With respect to internal loan, repayment was good according to64.45 per cent of members followed by very good repayment (22.22 per cent). Group pressure couples with flexible repayment structure in terms of number and amount of installments might be the reason for present findings. Only 13.33 per cent of SHG members were having a very poor internal loan repayment.

Nearer to fourth fifth members of SHG (78.89 per cent) opined that SHG had a democratic type of decision making patterns. This might be to ensure that each member feels responsible towards group decisions and also to maintain smooth functioning of the group. While only 11.11 per cent members said that two or three members took the decisions about SHG activities and other members follow them. This might be due to welleducated members and more old aged members in their group as they have more experience of work in a SHG or had taken more decisions. Remaining members (10.00 per cent) perceived that their SHG had an authoritative type of decision making pattern, means only one member takes the decision and other follow her decisions.

While in case of rising of conflicts, 77.78 per cent of the members of SHGs said that the conflicts rarely rose in their group followed by the conflicts was never raised (14.44 per cent).

This might be due to smoothly running of SHG with good coordination, unity and trustworthiness among each other. And only 7.78 per cent respondents replied that conflicts in SHG rose very frequently. The heterogeneity in attitude of the members towards certain issues like sanctioning loan, fixing interest rates, lack of coordination might be lead to conflicts. However, occasional conflicts would reflect upon the dynamism of the group.
From the above finding, it can be concluded that majority of the members (60.00 per cent) opined that monthly meeting is held in their SHG, while 50 to 75 per cent attendance was maintained by 51.11 per cent of the members, about three fourth of the members (74.45 per cent) conducted meeting by $\mathrm{NGO} /$ Mission Mangalam staff. Whereas, more than two third of members (67.78 per cent) contributed the fund as and when possible, 54.45 per cent of SHG members were written records by one of the member. Among the all SHG members records were moderately (not so neatly written) maintained (48.89 per cent),saving book amount matched with the passbook (63.33 per cent), members of their respective group had not transacting with the bank (52.22 per cent), participated in the extension programme conducted inside their village (56.67 per cent), participated in extension programme organized outside the village (53.33 per cent), group had availed revolving fund Rs. 25, 000 to Rs. 50,000 (64.45 per cent), regular in repayment of bank loan (56.67 per cent), repayment of internal loan (64.45 per cent), democratic type of decision making patterns (78.89 per cent) and conflicts rarely arise in their group (77.78 per cent).

\section{References}

Chinmayi, V., Beerannavar, B. and Raghuraja, J. 2015. Profile study of men Self Help Groups. Int. J. Sci. Eng. and Tech. Res., 4(11): 3733-3739.

Patel, D. B., Thakar, K. A. and Patel, K. S. (2011). Perception of the farmers about transfer of technology system in North Gujarat. Guj. J. Ext. Edu. 22(6): 17-20.

Patel, Sunil R., Patel, J. K. and Chandravadiya, K. U. (2016). Interpersonal Conflict among Employees of Agricultural Universities of Gujarat. Guj. J. Ext. Edu. 27(1): 4-7.

Priyakumari, S. V. 2015. A comparative study of SHG organised and promoted by 
SKDRDP and Kudumbashree in Dakshina Kannada district and Kollam district, towards empowerment of rural women. Ph.D. Thesis (Unpublished), Shri Dharmasthala Manjunatheshwara College, Ujire (Karnataka).

Sharma, D. D., Chand, M. 2014. Members' perception towards Self Help Groups: A study of Solan district of Himachal Pradesh. Int. J. Farm Sci., 4(2): 233239.

Sonawane, H. P. and Shirke, V. S. (2016).

Farmers Perception regarding Effects of Sewage Water on Crop and Human Health. Guj. J. Ext. Edu. 27(2): 130133.

\section{How to cite this article:}

Nakum Pooja, B., V.J. Savaliya, B.N. Kalsariya and Makwana, S.M. 2018. Perception Level of the Women about Performance of Self Help Group. Int.J.Curr.Microbiol.App.Sci. 7(11): 18731879. doi: https://doi.org/10.20546/ijcmas.2018.711.212 